Egyptian Journal of Aquatic Biology \& Fisheries

Zoology Department, Faculty of Science,

Ain Shams University, Cairo, Egypt.

ISSN 1110 - 6131 Vol. 21(3): 55-77 (2017)

www.ejabf.journals.ekb.eg

\title{
Zooplankton Community Structure of Lake Edku, Egypt
}

\section{Montaser, M. Hassan ${ }^{1}$; Magdy, T. Khalil ${ }^{1}$; Abd El-Halim, A. Saad ${ }^{1}$; Safwat, H. Shakir $^{2}$ and Gamal, M. EI Shabrawy ${ }^{3}$}

1- Department of Zoology, Faculty of Science, Ain Shams University

2- Prairie View A\&M University, Texas, USA

3- National Institute of Oceanography and Fisheries, Egypt

*Correspondence to Montaser, M. Hassan, Department of Zoology, Faculty of Science, Ain Shams

University, Egypt. E-mail: shmontaser2@gmail.com

\section{ARTICLE INFO}

Article History:

Received: June, 2017

Accepted: July, 2017

Available online: July, 2017

Keywords:

Lake Edku

Zooplankton

Community structure eutrophication

\section{ABSTRACT}

This research was designed to assess the impact of water quality on zooplankton community structure of Edku Wetland, Egypt. Zooplankton and water samples were collected seasonally from January to November 2004. Seven sampling stations were selected to represent different habitats of the Lake that were classified in this study to three distinct habitats; Body of the lake (BL), Drainage (D) and Lake- Sea Connection (LSC). Several physical and chemical parameters were studied, such as temperature, transparency, alkalinity, water $\mathrm{pH}$, chlorosity, electrical conductivity, water depth, dissolved oxygen (DO), chemical oxygen demand (COD), biological oxygen demand (BOD) and water hardness. Zooplankton community is composed of 72 species dominated by three groups; Rotifera, Copepoda and Cladocera. These groups were representing 89.5\%, $6.8 \%$ and $2.3 \%$ of total zooplankton density, respectively. The index of species abundance (ISA) and modified index of species abundance (MISA) showed that the small sized animals, such as Rotifera became the most dominant especially, genus Brachionus, which is considered as an indicator for organic pollution and eutrophication. Community ordination, trellis diagram and other biostatistical and multivariate analyses techniques showed that within the lake, similar ecological habitats have similar community structures for zooplankton and differ among different habitats. Comparing the present results with previous data of other researchers showed that zooplankton community shifted from dominance of Cladocera and large zooplankton species to rotifers and small zooplankton by increasing eutrophication.

\section{INTRODUCTION}

The fish production of Lake Edku may reach 19,000 tons, which is approximately a value added of $6000000 £$ to the Egyptian economy. There are about 
1700 fishing boats and more than 4000 fishermen working in the lake. It is subjected to various kinds of water pollution (Abdel-Moati and El-Sammak, 1997; Adham et al., 1999; Zaghloul and Hussein, 2000, Fathi et al., 2000 and Masoud et al., 2004) which influenced the water quality and biotic community especially eutrophication. The effect of increased nutrients in the freshwater has resulted in deterioration of the ecosystems worldwide. Changes in nutrient contents of the water also result in changes in community structure at each trophic level or within different taxonomic groups (Jeppesen et al., 2000). Eutrophication is defined as "the enrichment of water by nutrients causing an accelerated growth of algae and higher forms of plant life to produce an undesirable disturbance of the balance of the organisms present in the water and to the quality of the water (Jeppesen et al., 2007).

On the other hand, the importance of zooplankton as a heterogeneous assemblage of microscopic animals, in the trophic dynamics of freshwater ecosystems has long been recognized. These organisms, not only regulate the aquatic productivity, by occupying almost middle position in food chain, but also indicate environmental status in a given time as bioindicators (Ismail and Zaidin, 2015 and Sarkar and Saha, 2016). In addition, their diversity has assumed added importance during recent years due to the ability of certain species to indicate the deterioration in the water quality caused by pollution and eutrophication (Khan, 2003). Zooplankton organisms contribute significantly to the recycling of nutrients and provide a food base for predatory invertebrates and vertebrates (Sautour and Castel, 1997; Bedir, 2004).

Therefore, the objective of this study is to assess the impact of water quality changes on zooplankton community structure of Lake Edku.

\section{MATRIALS AND METHODS}

\section{1- Lake Description and Characteristics}

Lake Edku is a coastal wetland in the eastern Mediterranean and is located about $40 \mathrm{Km}$ eastern of Alexandria city and $18 \mathrm{Km}$ western of Rosetta branch of the River Nile. It is located west of the River Nile delta between longitudes $30^{\circ} 80^{\prime} 30$ " and $30^{\circ} 23^{\prime} \mathrm{E}$ and latitudes $31^{\circ} 10^{\prime}$ and $31018^{\prime} \mathrm{N}$. (Fig.1). The lake is connected to the adjacent Abu Qir Bay through Boughaz El Maadia.

There are two main drains discharge their wastes into the lake; namely ElKhayry and Barsik drains. The first drain is joined to three sources of drainage water coming from El-Bosely, Edku and Damanhour subdrains, which transport domestic, agriculture, and industrial wastewaters as well as the drainage water of more than 300 fish farms. The second drain transports mainly agricultural drainage water into the lake.

There are large quantities of the floating, aerial and submerged plants or hydrophytes covering about $50 \%$ of the lake surface area. These plants are Phragmites communis Trin. Ceratophyllun demersum, Potamogeton pectinatus and Eichormia crassipes (Mart.). The hydrophyte $C$. demersum and $P$. pectinatus represent the most abundant plants in the lake. This vegetation resist the movement of the fishing boats causes many problems to the fishermen and decreasing the surface area of the lake. After the mechanical control, it reaches now less than $30 \%$ of the total area where the mechanical excavators make roads of $25 \mathrm{~m}$ wide by cutting the plants under the surface of water. 


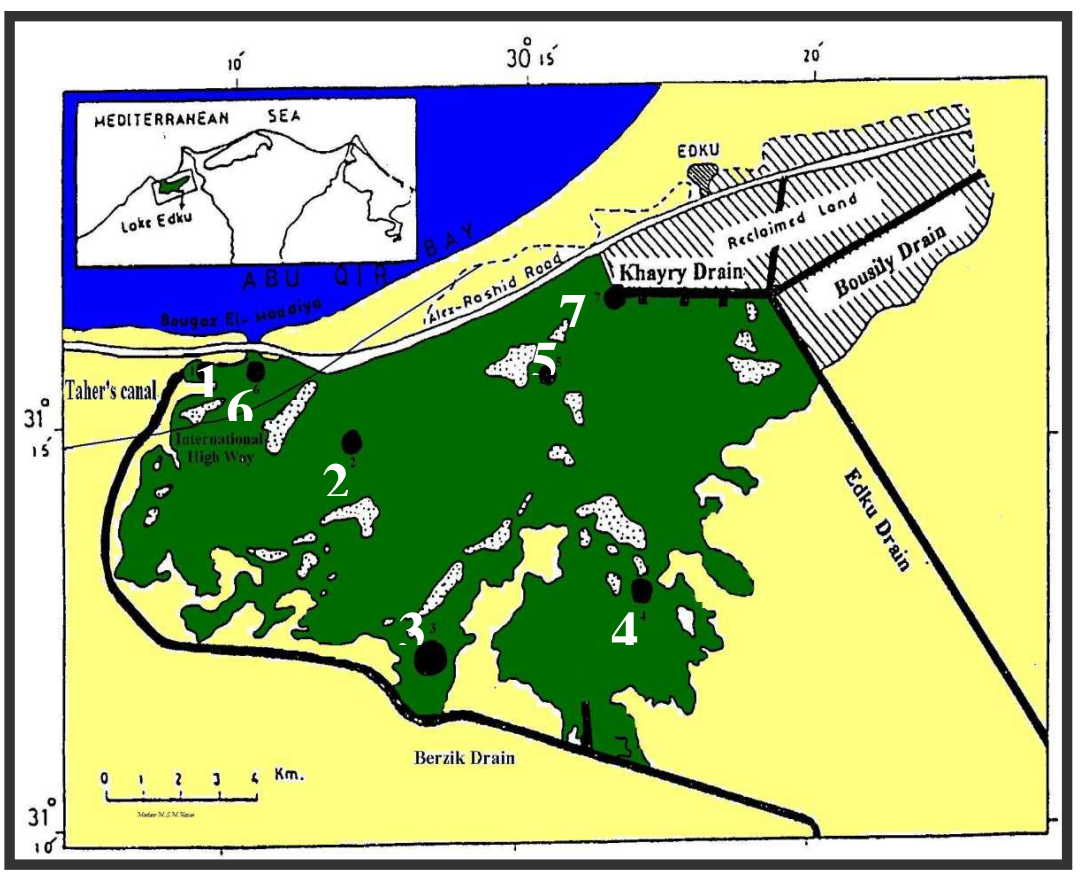

Fig. (1): Lake Edku showing the locations of different stations.

\section{2- Sampling Locations and Period of Investigations}

Water and zooplankton were collected seasonally all over one year from January 2004 to November 2004 from seven stations representing the different habitats of the lake (Fig. 1). These stations are:

1. Taher's canal at the end of Barzik Drain (St. 1)

2. Gezeret Al kotala (St. 2)

3. Bab Hassan (St. 3)

4. Gezeret El-Diyab in front of Bab Abdel Rahman (St. 4)

5. Gezeret El-Shalashel at the entrance of Bab Basala (St. 5)

6. Boughaz El Maadia (St. 6)

7. El-Khairy Drain (St. 7)

\section{3- Physico-chemical Parameters}

Hydrogen ion concentration $(\mathrm{pH})$, alkalinity, water hardness $\left(\mathrm{Ca}^{++}\right.$and $\left.\mathrm{Mg}^{+}\right)$, dissolved oxygen (DO), primary productivity, chemical oxygen demands (COD), biological oxygen demands (BOD) and salinity were seasonally measured during the year 2004 according to Standard Methods for examination of water and waste water, (APHA,1996). In the field, $\mathrm{pH}$ was measured immediately by 3070 Jen Way $\mathrm{pH}$ device. Water salinity and conductivity were measured by 4205 Jen Way salinity meter.

The dissolved nutrient salts such as ammonia $\mathrm{NH}_{3}$, nitrate $\mathrm{NO}_{3}$, nitrite $\mathrm{NO}_{2}$, phosphorous $\mathrm{PO}_{4}$ and reactive silicate $\mathrm{SiO}_{3}$ also were measured by spectrophotometric method according to Methods for examination of water and waste water, (APHA,1996) using Carl Zeiss spectrophotometer, Spicol. The water samples taken for analysis of nutrient salts were filtered through a Whatman glass microfiber filters "GF/C" using Bouchner device and a suction bump. The filtrate was stored at $80{ }^{\circ} \mathrm{C}$ until processing.

\section{4- Zooplankton Samples}

Zooplankton samples were collected vertically and horizontally by $55 \mu \mathrm{m}$ mesh size $30 \mathrm{~cm}$ diameter plankton net. The net was lowered to 1 meter depth from the ring of the net to the water surface, and then hauled vertically to the surface at a uniform speed. Another horizontal swap was taken by towing the net under the surface of the 
water for 10 meters distance at slow speed. Each sample was immediately preserved in $10 \%$ neutral formalin. Zooplankton was counted in $1 \mathrm{ml}$ using Carl Zeiss binocular stereomicroscope. This process was repeated three times. Zooplankton species were subjected to detailed examination and identification according to the following guides: Rutter-Kolisko (1974), Koste (1978), Sheil (1995), Einsle (1996) and Smirnov (1996).

\section{5- Data Treatment}

A. Absolute and Relative Importance values (AIV and RIV):

Data of zooplankton such as density (PD), biomass (BM), absolute frequencies (AF) and relative frequencies (RF) for each species were determined. These parameters were synthesized into the importance value indices (AIV and RIV) as calculated by Ghabbour and Shakir (1982), Shakir and Dindal 1997.

B. Diversity Indices and Multivariate Community Analysis:

In order to evaluate the diversity of zooplankton in different influence habitats in the lake, several indices were calculated according to Shannon and Weaver, Simpson, Menhinick's Index, Equitability and Richness were calculated and compared with Community Structure Diversity (CSD) Index ( Shakir, 1989, and Shakir Hanna 2004). Trends in zooplankton community in Lake Edku and studied habitats were illustrated by using a modification of dissimilarity ordination (Bray and Curtis 1957) for each sampling. Similarity trellis diagram was calculated as described by Mountford (1962).

C. Similarity and Abundance of Zooplankton Taxa:

Two types of similarity coefficients were used; Sorenson's index (Wallwork, 1976) is quantitative and used on presence or absence of species or taxa, and Gleason's formula is a quantitative method that utilizes the importance values (AIVand RIV) by equation (1) as follows:

$$
C_{s}=\frac{2 W}{A+B}
$$

Where $\mathrm{C}^{\mathrm{s}}$ is the similarity coefficient, $\mathrm{A}+\mathrm{B}$ is the sum of the quantitative measure of the two seasons (AIV and RIV), and W is the sum of the shared (lesser) values of the two seasons or two sites or habitats.

A further analysis of the zooplankton data of the different habitats in Lake Edku in Egypt was carried out by using an index of species abundance (ISA) (Roberts and His 1979). This method has the advantage of assessing the values of absence as well presence occurrences of species. It has an advantage in comparing of the faunal composition of the different habitats in the lake that have been formed or affected by different stresses through the course of human activities in the lake. This method provided an analysis of the most abundant species in the lake. Further, it can be of important in monitoring the structure of species composition changes in the lake.

The original ISA was calculated from equation (2) as the following:

$$
\frac{a+R_{s}}{K}
$$

1. Ranking of species abundance giving the lower rank to the most abundant species and highest rank to the rare species

2. If two or more species were having the same rank, everyone would take the average rank as if they were arranged in serial manner.

3. The maximum rank will be selected, this represent the minimal abundant species.

4. The number of blank cells for each species will be counted, this represents its absence.

5. Calculate $\mathrm{C}=$ maximum rank +1 
6. $\mathrm{a}=$ number of blank cells for each species $* \mathrm{C}$

7. $\mathrm{R}_{\mathrm{S}}=$ Sum of the ranks for each species

8. $\quad \mathrm{ISA}=\mathrm{a}+\mathrm{R}_{\mathrm{s}} / \mathrm{K}$ " $\mathrm{K}=$ number of columns"

The original ISA has some weak points where, the most abundant species will take the minimum ISA value furthermore; the rare species will get higher value. Additionally, the absent species will get the value of " $\mathrm{C}$ " which is the highest ISA value. Therefore, if we are comparing some communities to each other, the absent species will get closely approximated ISA values, thus it will cause a problem.

The modification of ISA will be achieved as following:

1. Ranking of the species where the most abundant species will get the highest rank.

2. The maximum rank in the table will be selected, representing the most abundant one.

3. Counting of the non-zero cells for each species, which represent the presence of that species.

By doing these steps in addition to the steps mentioned above (i.e. the remaining steps of the ISA), then the most abundant species will get the highest Modified Index of Species Abundance "MISA" value and the value will decrease as the density of the species decrease. Furthermore, the MISA value for the absent species will be zero.

\section{6- Statistical analysis}

Most dependent variables, that is, density and biomass, were analyzed separately by means of a factorial design (ANOVA) (Sokal and Rohlf 1981). Main effects were the environmental variables such as $\mathrm{pH}$, water temperature, salinity, and other elements that were studied as described in the data collected. These factors were used for determination whether or not differences between the physical-chemical characteristics of the stations and habitat classifications were significant. Therefore, general linear model (GLM) of multivariate analysis of variance (MANOVA) was carried out using the STATGRAPHICS (1986) and SAS 9.1.3 (2007) for Windows software programs on PC as an authorized license of Texas A \& M University to Prairie View University. Statistical significance was implied at the probability of 0.05 or less in this dissertation.

Results of regression and correlation analyses were used for explaining the relationship between the environmental, parameters and zooplankton. Most of regression and correlation analyses were done on transformed data.

\section{RESULTS AND DISCUSSION}

\section{Zooplankton Density and Biomass}

\section{- Zooplankton Community Structure}

Seventy-two species of zooplankton were identified in the present survey. The zooplankton community was dominated by three main groups; Rotifera, Copepoda and Cladocera (Fig. 2). Their annual average densities were 295275, 19465.18 and $8205.357 \mathrm{ind} / \mathrm{m}^{3}$ with percentages $90.35 \%, 5.96 \%$ and $2.51 \%$, respectively, (Table 1). Protozoa and meroplankton groups were represented only by $26.78 \mathrm{ind} / \mathrm{m}^{3}$ and $3855.357 \mathrm{ind} / \mathrm{m}^{3}$ with a percentage of $0.01 \%$ and $1.17 \%$ of the total number of zooplankton. As indicated in Table (2), although Cladocera group is less represented than copepods but they have higher biomass. On the other hand, dominance of rotifers may be due to the habitat preference where favorable ecological parameters are present and their food requirements (phytoplankton) are available in excess. The other factor that makes certain group or species dominating the other is the absence of 
invertebrate predators of such organisms (Aboul Ezz and Soliman, 2000; Abdel Aziz and Dorgham, 2005).

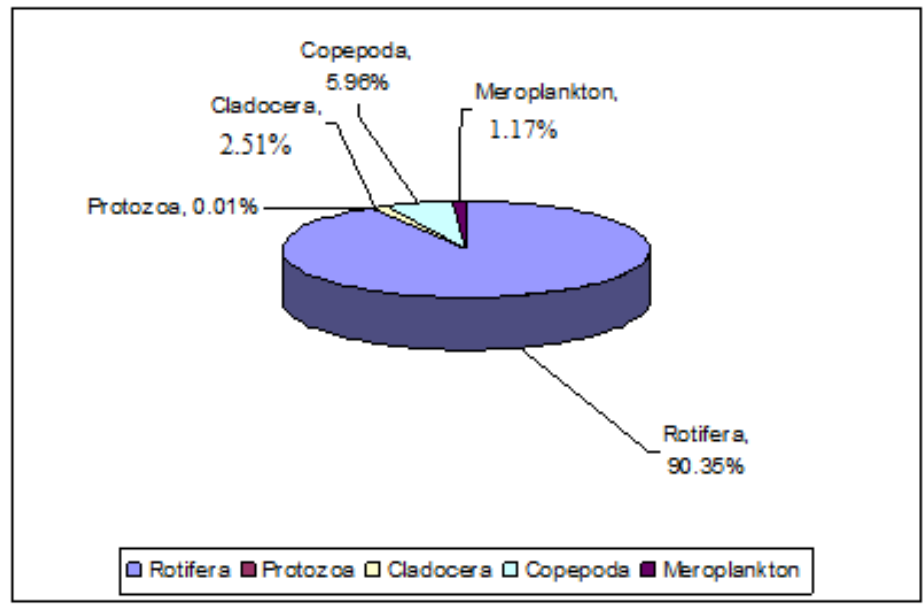

Fig. (2): Community structure of zooplankton in Lake Edku during the period of the study

Table (1): Percentages of important species to the total population density, total biomass, and total density of each group and functionality of the species.

\begin{tabular}{|c|c|c|c|c|c|c|}
\hline Species & Function & $\begin{array}{l}\% \text { to the } \\
\text { group }\end{array}$ & $\begin{array}{c}\% \text { to } \\
\text { TZD }\end{array}$ & Species & $\begin{array}{ll}\% & \text { to } \\
\text { TZB }\end{array}$ & $\begin{array}{l}\text { BM } \\
\text { per } \\
\text { ind. }\end{array}$ \\
\hline B. calyciflorus & Herbiv. & $36.8 \%$ & $33.22 \%$ & B. calyciflorus & $14.60 \%$ & 0.45 \\
\hline$B$, angularis & Herbiv. & $30 \%$ & $27.08 \%$ & B. angularis & $10.58 \%$ & 0.4 \\
\hline B. plicatilis & Herbiv. & $9.2 \%$ & $8.32 \%$ & M. micrura & $10.26 \%$ & 11.6 \\
\hline P. vulgaris & Herbiv. & $8.1 \%$ & $7.34 \%$ & A. tragani & $9.50 \%$ & 18.24 \\
\hline K. quadrata & Herbiv. & $5.5 \%$ & $4.96 \%$ & B. plicatilis & $5.04 \%$ & 0.62 \\
\hline Nauplius larva & Deteriv. & $66.2 \%$ & $3.95 \%$ & B. longirostris & $4.38 \%$ & 5.2 \\
\hline B. urceolaris & Herbiv. & $2.2 \%$ & $2.02 \%$ & Nauplius larva & $2.85 \%$ & 0.74 \\
\hline $\begin{array}{l}\text { Cyclopoide } \\
\text { Copipodid }\end{array}$ & Herbiv. & $16 \%$ & $0.97 \%$ & $\begin{array}{l}\text { Cyclopoid } \\
\text { copipodid }\end{array}$ & $2.56 \%$ & 2.7 \\
\hline M. micrura & Herbiv. & $34.7 \%$ & $0.91 \%$ & D. excisum & $1.52 \%$ & 6.2 \\
\hline B. longirostris & Herbiv. & $33.1 \%$ & $0.86 \%$ & K. quadrata & $1.45 \%$ & 0.3 \\
\hline A. tragani & Predator & $9 \%$ & $0.53 \%$ & C. reticulata & $1.43 \%$ & 11.16 \\
\hline D. excisum & Herbiv. & $9.62 \%$ & $0.25 \%$ & B. urceolaris & $0.83 \%$ & 0.42 \\
\hline A. rectangula & Herbiv. & $8.58 \%$ & $0.22 \%$ & A. rectangula & $0.77 \%$ & 3.5 \\
\hline C. reticulata & Herbiv. & $5.02 \%$ & $0.13 \%$ & P. vulgaris & $0.29 \%$ & 0.04 \\
\hline
\end{tabular}

Table (2): The importance indices and ISA of the most important zooplankton species in the studied

\begin{tabular}{lrrrrrr}
\multicolumn{1}{c}{ habitats of Lake Edku } & AF & RF & AIV & RIV & ISA & MISA \\
\hline Species & 100 & 3.85 & 11.7 & 53.0 & 1.50 & 144.50 \\
\hline B. calyciflorus & 100 & 3.85 & 11.4 & 41.3 & 1.50 & 144.50 \\
B. angularis & 75.00 & 2.88 & 9.7 & 13.3 & 13.25 & 132.75 \\
M. micrura & 67.86 & 2.64 & 8.3 & 9.7 & 15.38 & 130.63 \\
A. tragani & 96.43 & 3.71 & 10.1 & 15.5 & 5.75 & 140.25 \\
B. plicatilis & 67.86 & 2.61 & 9.3 & 8.1 & 11.25 & 134.75 \\
B. longirostris & 100 & 3.85 & 10.0 & 10.8 & 5.50 & 140.50 \\
Nauplius larva & 96.43 & 3.71 & 9.4 & 7.4 & 10.13 & 135.75 \\
Cyclopoid copipodid & 39.29 & 1.53 & 6.3 & 3.2 & 29.75 & 94.88 \\
D. excisum & 82.14 & 3.18 & 8.6 & 10.5 & 16.00 & 129.88 \\
K. quadrata & 46.43 & 1.77 & 7.7 & 2.7 & 25.63 & 120.38 \\
A. rectangula & 32.14 & 1.22 & 6.0 & 2.9 & 35.36 & 89.00 \\
C. reticulata & 100 & 3.85 & 9.2 & 6.8 & 6.75 & 139.25 \\
B. urceolaris & 96.43 & 3.72 & 9.2 & 10.9 & 4.25 & 141.75 \\
P. vulgaris & & & & & &
\end{tabular}




\section{- Species Composition of Zooplankton Community}

Rotifera was represented by 36 species in the present survey. It was dominated by six species namely, Brachionus calyciflorus $\left(108571.4 \mathrm{ind} / \mathrm{m}^{3}\right)$, B. angularis $\left(88500.0 \mathrm{ind} / \mathrm{m}^{3}\right)$, B. plicatilis $\left(27178.6 \mathrm{ind} / \mathrm{m}^{3}\right)$, Brachionus urceolaris $(6589.3$ ind $\left./ \mathrm{m}^{3}\right)$, Polyarthra vulgaris $\left(23982.1 \mathrm{ind} / \mathrm{m}^{3}\right)$ and Keratella quadrata (16214.3 ind $\left./ \mathrm{m}^{3}\right)$ (Table 1). In addition, K. quadrata attained higher biomass $\left(29 \mu \mathrm{g} / \mathrm{m}^{3}\right)$ than $P$. vulgaris $\left(959.28 \mu \mathrm{g} / \mathrm{m}^{3}\right.$ ) (Table 2$)$. As indicated in the density and biomass matrix, the genus Brachionus is the most abundant one in the studied ecosystem. The species, $B$. calyciflorus and $B$. angularis contributed together about $60 \%$ of the total zooplankton density. Additionally, they have the highest AIV, RIV, AF, RF and MISA values which indicated their importance in the lake ecosystem as most dominant, frequent and abundant species. The dominance of this genus could be due to its high reproduction rate and habitat preference since their food such as phytoplankton or plant detritus are highly available. Zooplankton community was dominated by the herbivorous rotifers, B. calyciflorus, B. angularis, $B$. urceolaris this may be attributed to their special characteristics, high availability of phytoplanktonic food due to the increased eutrophication (Lijing et al., 2012 and Bielan'ska-Grajner et al., 2014) and absence of their predators. Aboul Ezz and Soliman (2000), Zaghloul and Hussein (2000), Hobaek et al. (2002) and Ali et al. (2007) reported similar results. They illustrated that, the gut contents of these species were dominated by Certeria and Euglena; which are more common in Lake Edku (Gharib, 1999). Further, Dunn (1985) and Uku and Mavuti (2001) established that, rotifers are less preferred than Cladocera and Copepoda by Oreochromis, which represent $82 \%$ of the total fish in Lake Edku (Sainty, 1985). Furthermore, the dominance of rotifers may be due to the decreased heterogeneity of the studied ecosystem and its dominance by organicly polluted water. Hrodey et al. (2008) stated that, decreased habitat heterogeneity could lead to an increased abundance of highly adaptive taxa, which out-compete individuals that are more sensitive and dominate community composition.

Copepoda (Arthropoda, Crustacea) was represented by fourteen species. It was dominated by nauplius larvae $\left(12894.643 \mathrm{ind} / \mathrm{m}^{3}\right), 66.2 \%$, of the total copepods Table (1) and immature cyclopoide copepodid, $\left(3167.9 \mathrm{ind} / \mathrm{m}^{3}\right), 16 \%$ whereas, the adult, Acanthocyclops tragani contributed $1742.86 \mathrm{ind} / \mathrm{m}^{3}, 9 \%$ of the total copepods. Dominance of immature stages may be due to the influence of eutrophication however, the low abundance of adults may be due to some predator fish that attracted to the large-sized adults than small-sized immature stages. This could be illustrated by the lower density and higher biomass of the large-sized adults. Additionally, the higher AF, RF and MISA values of the immature stages may confirm this observation. Furthermore, the ISA of immature stages was lower than that of the adult stages.

Cladocera or water fleas (Arthropoda, Crustacea) are considered biological indicators for water quality and pollution. In the studied ecosystem, Cladocera was represented by only eight species. Two species were the most dominant in the group namely, Moina micrura (2960.71 ind $\left./ \mathrm{m}^{3}\right)$, comprising $34.68 \%$ of the total Cladocera Table (1) and Bosmina longirostris (2821.43 ind $\left./ \mathrm{m}^{3}\right), 33.05 \%$. These are small-sized Cladocera however, the large-sized species such as Diaphanosoma excisum, A. rectangula and Cirrodaphnia reticulata are less dominant and consequently; they have lower values for AIV, RIV, AF, RF and MISA. Accordingly they contributed the highest ISA. Larger size species (e.g. Daphnia) are no longer found in the lake although they were the most dominant group several years ago. This was confirmed by El-Hawary (1960) and Samaan (1976). Furthermore, the low number of Cladocera in the community could be attributed to the predation, eutrophication or pollution of the water body, where Cladocera cannot survive in polluted waters and change of 
water characteristics led to corresponding changes in the zooplankton community (Flower, 2001)., additionally; more predators are attracted to them (Forneman et al., 2002; Gaudy et al., 2004).

The four species, $B$. calyciflorus, $B$. angularis, Moina micrura and Acanthocyclops tragani comprised together about $45 \%$ of the total zooplankton biomass. Although rotifer species are small in size but they have the highest biomass. On the contrary, A. tragani, M. micrura and B. longirostris have higher biomass per individual and lower population density than the rotifers, $B$. angularis and $B$. plicatilis. This may indicate their importance in the food web, where, larger species with higher biomass are more satisfactory for predators than the smaller rotifer species. These may explain the higher predation impact on cladocera and adult copepods and their role in the food web. Similarly, the biomass of Cladocera was higher than that of copepods, which may indicate that Cladocera are more attractive to predators than copepods and consequently they have more important role in the food web (Lair, 2005; Ali et al., 2007).

\section{- Seasonal Distribution of Zooplankton}

The average total density of zooplankton started to increase during spring and reached its peak in summer; then started to decrease during autumn until reaching its minimum level in winter. Rotifera followed the same pattern of seasonal variation of zooplankton where, summer was the season of highest production of these organisms with an average standing crop, $383942.9 \mathrm{ind} / \mathrm{m}^{3}$. The lowest population density was recorded during winter, $211514.29 \mathrm{ind} / \mathrm{m}^{3}$. This may be due to the increased water temperature during summer, which accelerated the egg development and hatching rate of most zooplankton such as rotifers (Froneman et al., 2002; El-Shabrawy and Dumont, 2004; Bedir, 2004; Mageed, 2005; Lair, 2005; Ali et al., 2007). They attributed this increase to the increased rate of egg hatching and development of the planktonic groups especially Rotifera. However, they attributed the decrease in winter to the increased salinity, water current and turbidity due to the wind action. These are known to affect zooplankton populations through several mechanisms including decreased assimilation efficiency and filtering rates.

The average standing crop of copepods showed its peak, $29975.0 \mathrm{ind} / \mathrm{m}^{3}$ during winter, followed by summer, $21114.29 \mathrm{ind} / \mathrm{m}^{3}$. The minimum density was 12985.71 $\mathrm{ind} / \mathrm{m}^{3}$ during autumn. Similar fluctuations were observed for the biomass. This may be due to the adult copepods entered with seawater then decreased gradually due to decreased salinity. The increase during summer may be related to egg hatching and increase of immature stages. Wolfnbarger (1999) and Bedir (2004) supported this result. In addition, this is confirmed by the positive correlation between temperature and zooplankton density and biomass. Froneman (2004), Bedir (2004) and Mageed and Heikal (2006) agreed with these results. Furthermore, Mageed and Heikal (2006) established the dominance of nauplii and immature stages over the adults. Williamson and Bulter (1986) and Williamson (1987) mentioned that, dominance of immature stages of copepod community is caused by eutrophication of the water body.

Cladocera displayed more or less different pattern of distribution from that observed for total zooplankton. The average standing crop of Cladocera reached its peak in winter, $11421.0 \mathrm{ind} / \mathrm{m}^{3}$ followed by summer $\left(9929.0 \mathrm{ind} / \mathrm{m}^{3}\right)$ while the lowest density was in autumn, $\left(5114.0 \mathrm{ind} / \mathrm{m}^{3}\right)$. The increase of Cladoceran density in winter could be due to the increased oxygen content of the water because of decreased temperature and increased water movement. This increase was in the sites far from the sea in the center of the lake. Additionally, some species might prefer cold weather for their egg hatching. This was in agreement with the results of Ropert et al. (1983), Wolfnbarge (1999), Fathi et al. (2000), Abdel Aziz and Dorgham (2005), Kuczynska- 
Kippen and Nagengast (2006) and Martinez-Jeronimo and Martinez-Jeronimo (2007). They attributed this increase to M. micrura and B. longirostris, which are the most dominant cladoceran species in this study and they increase during winter. They clarified that, large cladocerans are usually restricted to freshwater environment; however, those inhabiting brackish waters are smaller in size and have reduced reproduction. This was confirmed by El-Hawary (1960) and Samaan (1976) where the large caldoceran species Daphnia was dominating the lake but it is not found now. Abul Ezz and Soliman (2000) and Flower (2001) established the former freshwater nature of Lake Edku water and change of water characteristics led to corresponding changes in the zooplankton community.

\section{- The Role of Inter-Specific Interactions in Shaping Zooplankton Community Structure}

Not only physico-chemical variables influenced zooplankton community structure, but also there is a strong effect from the biotic component of the aquatic ecosystem upon each other (e.g.) grazing of herbivorous zooplankton upon the phytoplankton and predation of vertebrate and invertebrate predators on the herbivorous zooplankton. These interactions strongly influence the community composition (Zhao et al. 2008). In Lake Edku, small-size Rotifera dominated the zooplankton community. This may be due to that most fishes and other vertebrate predators do not prefer them. Furthermore, the larger zooplankton species such as copepods and Cladocera are limited as they are preferable by the predators. This was confirmed by Vinebrooke et al. (2004) and Uku and Mavuti (1999), who illustrated that, gut content of Oreochromis spp., indicated that Copepoda and Cladocera are more preferable than Rotifera. Some predators are selective, however others may feed on another prey if their favorable food is not present (Bogdan and Gilbert, 1984). Additionally, many of the rotifer species possessed morphological and behavioral characteristics that drastically reduced their vulnerability to predation, such as genus Brachionus that has lorica with long spines. This genus is the most common in Lake Edku, whereas soft-bodied species are less dominant as they are more vulnerable to predation. This agreed with the results reported by Ruttner-Kolisko (1974), Williamson (1987), Lair (2005) and Ali et al. (2007). In addition, the most widespread predators of planktonic rotifers especially Brachionus, is the copepod Mesocyclops edax, (Williamson, 1983 and 1984; Williamson and Bulter, 1986); this predator is not found in Lake Edku. The present study revealed that copepod community was dominated by small sized immature stages and nauplii. This may illustrate the high predation rate on the large sized adult planktonic species, where many species of fish select the largest prey that they can see. The rotifers and nauplii can escape because they are too small in size or because they provide negligible meal if compared with the effort of catching it (Jeppesen et al., 2007; Zingel and Haberman, 2008). The same for Cladocera where Bedir (2004), Abdel Aziz and Dorgham (2005), \& Mageed and Heikal (2006) postulated that Cladoceran species are exclusively filter feeder and algae user, as well as it is the favorite prey for both invertebrate and vertebrate predators. Therefore, predation may limit the species composition in the community and may illustrate the dominance of Rotifera. Furthermore, this was confirmed by the strong significant correlation between total Copepoda and total Cladocera in the present work. This may illustrate predation effect from copepods on adult cladocerans or their eggs (Wolfnbarger, 1999; Forneman et al., 2002; Gaudy et al., 2004; Costa et al., 2006). Williamson and Bulter (1986) established that, copepods were feeding on the cladoceran eggs inside their brood pouches. Accordingly, the zooplankton functionality has an important role in shaping zooplankton community structure (Thebault and Loreau, 2006). 


\section{- long-Term changes of Zooplankton Community Structure}

Aquatic ecosystems are considered as the most impacted habitats as a result of human activities; these stresses represent one of the most important factors in shaping and limiting the density, diversity and community structure of zooplankton (Xiong et al., 2016). Historical long-term studies revealed that Lake Edku was poor in zooplankton due to its mesotrophic properties (Samaan, 1976). After that, the density of rotifers increased from 248300 to $295275 \mathrm{ind} / \mathrm{m}^{3}$, percentage from 76 to $89.42 \%$ in the last four years, however species number decreased from 49 to 36 species. This may be due to increase of drainage water, nutrients and eutrophication. This was supported by Odum (1997), Aboul Ezz and Soliman (2000), Bedir (2004) and Yildiz et al. (2007); they stated that in freshwater systems zooplankton abundance increase by increasing eutrophication especially rotifers which are characteristic for eutrophic and organically polluted waters. Additionally, Rogozin (2000) pointed that the trophic status of the water body is closely related to the structure of zooplankton community. They are sensitive for pollution and eutrophication (Ismail and Zaidin, 2015). Further, Zingel and Haberman (2008) added that, fundamental changes have recorded in zooplankton composition of Lake Edku due to the increased eutrophication, where oligo-mesotrophic species have almost totally disappeared. In addition, RuttnerKolisko (1974) advocated that the number of species at first increase with the eutrophication of the water up to certain point and then decrease again. Fisher et al. (1943) stated that in the healthy ecosystem, the number of species increases over the long period, however in the present case eutrophication led to poor and degraded ecosystem in which the number of species decreased with time. Moreover, Vaughn and Hakenkamp (2001) and Saad (2003) found that increased eutrophication may cause sudden mass mortality of aquatic organisms due to high oxygen consumption by increased phytoplankton and aquatic vegetation. This may indicate the declining of fish in the Lake Edku due to its pollution, therefore Rotifera still the most dominant group. This was supported by Abdel-Aal and Talaat (2000) and Nafea (2005); who reported that the predominance of small sized fish over older age group which were represented in small proportions or even absent, reflecting decreasing and the higher mortality of fish. Therefore, Lake Edku has the lowest species number of fish among the Delta lakes. In addition, Aboul-Ezz and Soliman (2000) reported that changes occurred in zooplankton community was attributed to the increased densities of hydrophytes, diatoms, phytoplankton, and bacterial growth, leading to oxygen consumption which hinders the growth of zooplankton.

Increased human activities in the aquatic habitats influence the species composition of the local communities or species sorting (Xiong et al., 2016). Cladocera was dominating Lake Edku in late seventies and early eighties followed by copepods, while Rotifera was rare group or even absent as indicated by El-Hawary (1960) and Samaan (1976). After that, rotifers highly increased and became the most dominant group until now. El-Shabrawy and Dumont (2004) stated that, at times and places where cladoceran densities were high, rotifer density tended to be low. This may indicate the control effect of cladocera on rotifera. Additionally, Williamson (1987) found crushed rotifers in the food chamber of Daphnia. On the other hand, Cladocera showed a very minute increase in density. Figures (3 and 4) reflecting parallel increase of total rotifers density by increasing the nutrient salts. This was accompanied by a parallel decrease of cladocerans density indicating that they can hardly survive under the present stressors such as suspended sediments that decrease their filtering ability and assimilation rates. This agreed with the results reported by Wolfinbarger (1999) and Yildiz et al. (2007). Moreover, El-Hawary (1960) reported that, large sized Cladocera, especially Daphnia, were characteristic for Lake Edku, 
however, genus Brachionus was not found in Edku as it is highly increases in eutrophic and organically polluted water bodies. These results agreed with those reported by Ruttner-Kolisko, (1974), Sladecek (1983), Aboul-Ezz and Soliman (2000), Vinebrooke et al. (2004), Bedir (2004), Mageed (2005) and Jeppesen et al. (2007). Similarly, Williamson and Bulter (1986), Williamson (1987), Zingel and Haberman (2008) and Ismail and Zaidin (2015) established that small size zooplankton organisms (e.g. Rotifera, Chydorus, Bosmoin, etc.) are known to be eutrophication indicators and they can assess the condition and changes in the aquatic ecosystem.

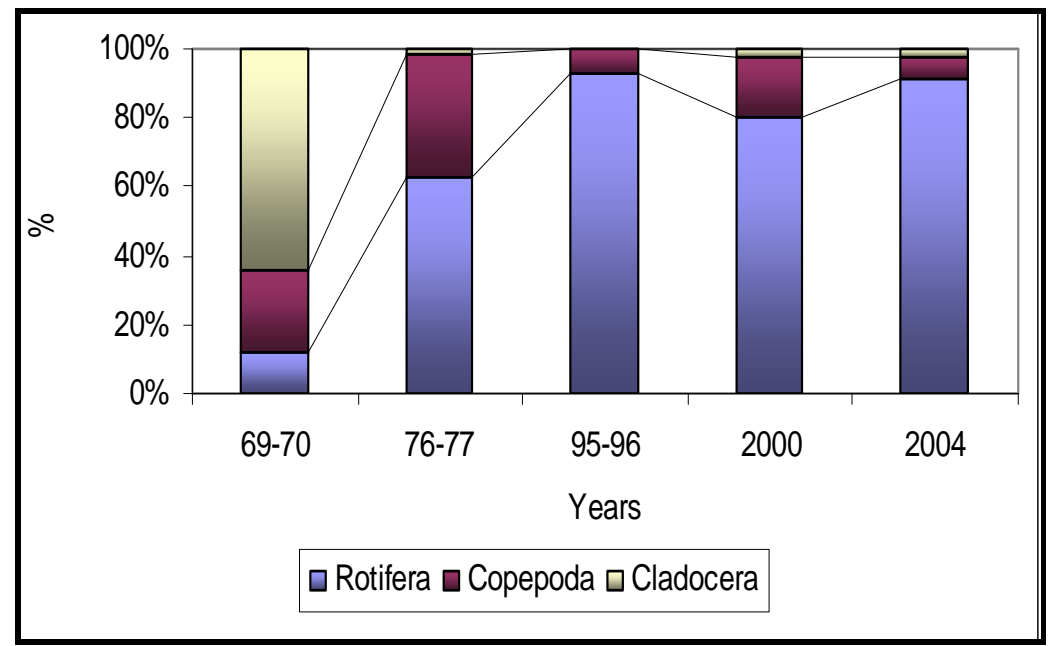

Fig. (3): Long-term changes of zooplankton community in Lake Edku.

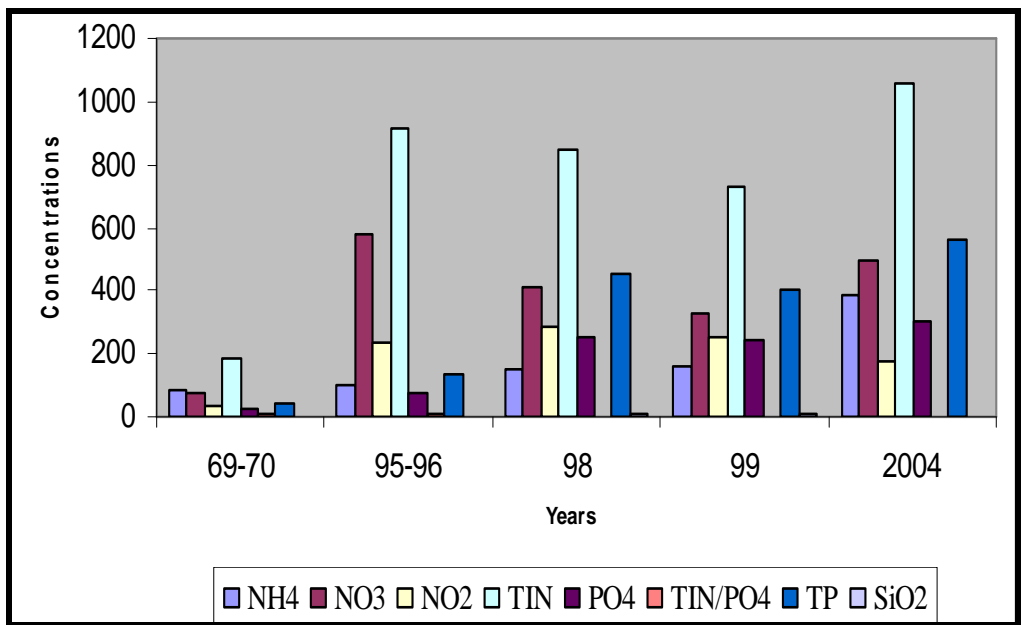

Fig. (4): Long-term changes of nutrient salt concentrations in Lake Edku.

Nematode plankters showed a remarkable increase from 2650 to $7103 \mathrm{ind} / \mathrm{m}^{3}$ and from 0.8 to $2.15 \%$. This may be attributed to the increase of hydrophytes due to increased nutrients and plant detritus as indicated by El-Hawary (1960), Samman (1977), Fahmy et al. (1996), Gharib (1999), Gharib and Dorgham (2000) and Ali et al. (2007), moreover, aquatic vegetation influences the distribution of nematode community in coastal wetlands (Du et al., 2014).

\section{Effect of Physico-Chemical Parameters on Zooplankton}

According to analysis of ecological parameters, the most important factors affecting the lake water environment are temperature, $\mathrm{pH}$, ammonia, $\mathrm{BOD}, \mathrm{Mg}, \mathrm{SD}$, $\mathrm{SiO}_{3}$ and salinity. These factors are affecting the zooplankton density, biomass and species composition. 
Aquatic organisms are indirectly affected by air temperature through its effect on water temperature, the later can directly influence aquatic organisms especially plankton. Figure (5) illustrates the positive correlation between both air temperature (AT), water temperature (WT) and total zooplankton density (TZD), (AT ( $\mathrm{r}=0.36$ and $\mathrm{P}<0.05)$ and $\mathrm{WT}(\mathrm{r}=0.33$ and $\mathrm{P}<0.05))$. This is due to the direct effects of water temperature on the physiological activities of zooplankton such as metabolism, egg development and hatching. Water temperature was following that of the air. There were no abnormal thermal changes in the lake. Samaan (1974, 1976) and Saad (2003) supported this result and indicated that Lake Edku has a uniform water temperature due to the shallowness and continuous water flow. These results came in harmony with that recorded by Froneman et al. (2002) and Telesh (2004) who advocated that these ecosystems are characterized by the virtual absence of horizontal gradient in temperature; this is due to the low depth, which facilitates horizontal and vertical mixing of the water column.

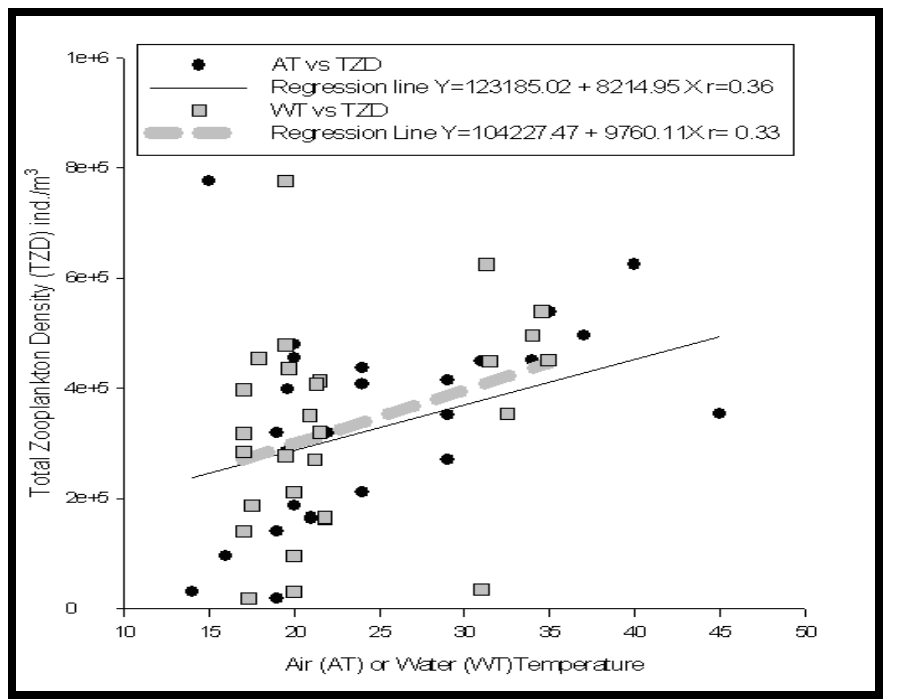

Fig. (5): Relationship between total zooplankton density (TZD), air temperature (AT) and water temperature (WT).

A significant positive influence of water $\mathrm{pH}$ on total zooplankton and total rotifers densities was found in Figure (6), $(r=0.54435 \mathrm{p}<0.0027$ and $r=0.5249 \mathrm{p}<$ 0.0041 respectively). This may be explained by the preference of alkaline medium by rotifers where most of them have a lorica and lower $\mathrm{pH}$ may affect this lorica and consequently their life. The lowering in $\mathrm{pH}$ value in station 5 is due to the water discharge from El-Khairy drain. This result agreed with those reported by Abbas et al. (2001) and Shakweer (2006). El-Khairy Drain was having lower pH than Taher Drain because the later carries agriculture discharge with high nutrient load and phytoplankton that make photosynthesis consuming the $\mathrm{CO}_{2}$, while the other is carrying mainly industrial and domestic wastes, which decrease the $\mathrm{pH}$ values This was supported by Shakweer and Abbas (2005). The low $\mathrm{pH}$ in the lake-sea connection, especially in the winter, is attributed to the entrance of seawater from Abu Qir Bay carrying industrial pollutant. These results matched with those reported by Moore (1989) and Youssef (2003). The increased $\mathrm{pH}$ during summer was explained by Samaan (1974), Moore (1989) and Michaud (1991) who reported that the peaks of $\mathrm{pH}$ were recorded during spring and summer due to increased photosynthesis, primary production of phytoplankton and growth of hydrophytes. 


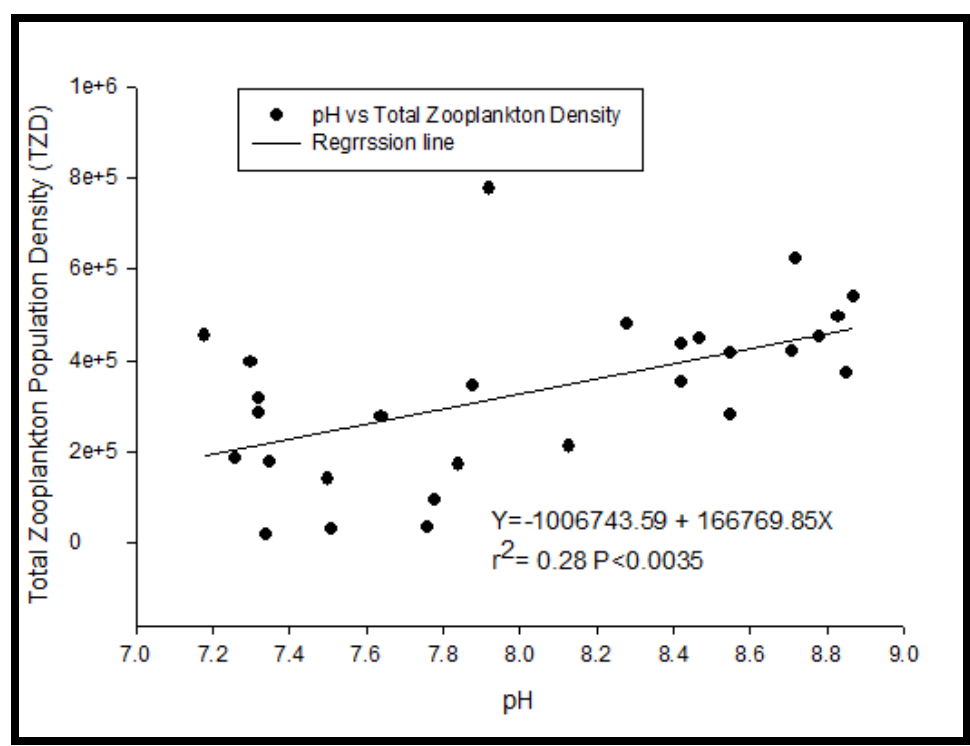

Fig. (6): Relationship between total zooplankton density (TZD) and pH.

The total zooplankton density has a significant relationship with $\mathrm{pH}$ and water temperature. The density increased with increasing $\mathrm{pH}$ and increasing water temperature. Figures $5 \& 6$ graph can explain that the highest density of zooplankton can be of importance for both highest temperature and highest values of $\mathrm{pH}$ (i.e. the regression line was significant $\mathrm{r}^{2}=0.48$ and $\mathrm{P}<0.01$ ). The regression line for this three dimensional graph can show the impact of environmental parameters on the zooplankton. It is clear that zooplankton has significant temperature sensitive association with $\mathrm{pH}$ that can be of importance in affecting population growth activities.

The biological oxygen demand (BOD) indicates the presence of microbial activities and organic matter on which microbes can feed. Therefore, BOD is directly linked with decomposition of dead organisms in the aquatic ecosystem and hence, the higher values of (BOD) can be considered as an indicator for the pollution status of the water body. The more oxygen consumed, the hardly organisms can survive. Therefore, in the present study BOD was negatively correlated to the total zooplankton density and biomass (Fig. 7). This is attributed to the increased oxygen consumption required for oxidation of the organic matter in the water body. The total zooplankton density showed lower density when BOD has the lowest values.

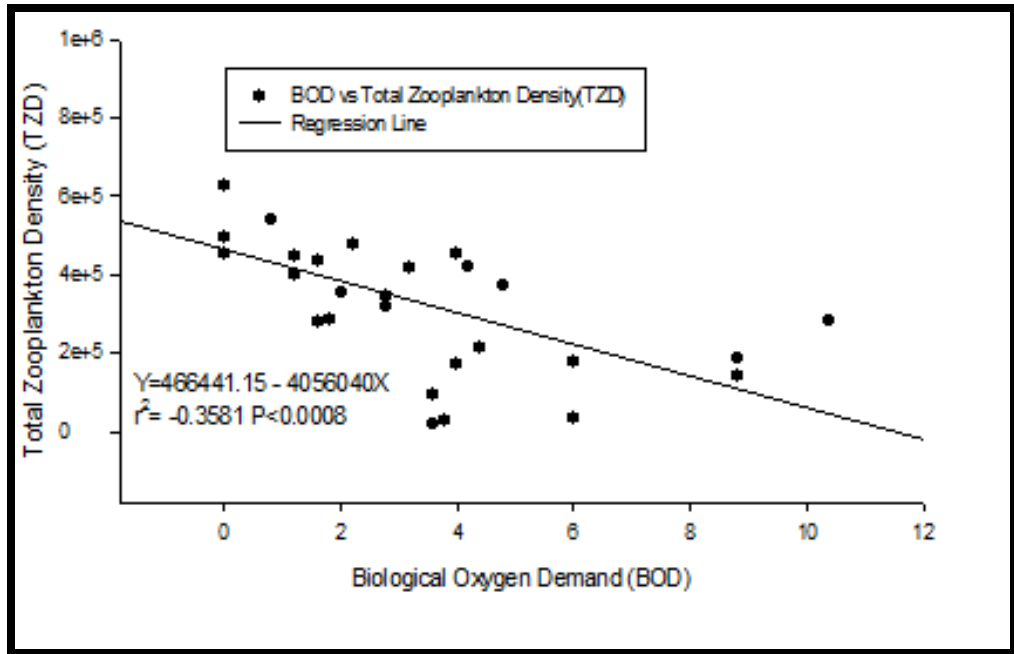

Fig. (7): Relationship between biological oxygen demand (BOD) and total zooplankton density (TZD). 
The present results clarified that DO concentration is high during winter; however it was low during summer. This is in agree with Khalil et al. (2000), Jacob (2002), Telesh (2004), Mogias and Kevrekidis (2005) and Mageed (2005). They attributed it to the effect of high wind action and water current during winter that increases the DO. On the other hand, stagnation period and high temperature during summer decreased the dissolved oxygen concentration in the water. Furthermore, Comita (1968) and Bishop (1968) explained that, oxygen consumption rate increases during summer, and decreases DO concentration. On the contrary, Fathi et al. (2000) disagreed with the present results and reported that the maximum dissolved oxygen was during summer while the lowest was in spring. Generally, dissolved oxygen concentration in the drainage water was low if compared to that in the lake due to its consumption in oxidation of chemical compounds and organic matter found in the water. The chemical oxygen demand (COD) was higher in the drains than that of the lake due to their higher contents of oxygen demanding chemicals and organic matters in their waters. Abbas et al. (2001) supported these results. The average value of COD in all habitats was above $40 \mathrm{mg} / \mathrm{l}$, therefore the lake is considered as polluted water body according to Musa and Hector (2005), who stated that water bodies having COD $>40 \mathrm{mg} / \mathrm{l}$ are considered as contaminated waters, while those having COD > $120 \mathrm{mg} / \mathrm{l}$ are highly contaminated.

Total zooplankton density and biomass showed significant negative correlation with the concentration of ammonia in the water (Fig. 8). Increased ammonia is considered as a kind of toxins for the aquatic organisms therefore, (TZD) and consequently (TZB) decreased as ammonia increased. Ammonia consumes dissolved oxygen (DO) to be oxidized to nitrate by the microorganisms that in turn decreases the available oxygen for aquatic organisms and consequently their density and biomass decreases. This was confirmed by the negative influence of the increase of $\mathrm{NH}_{4}$ and $\mathrm{PO}_{4}$ on the (TZD).

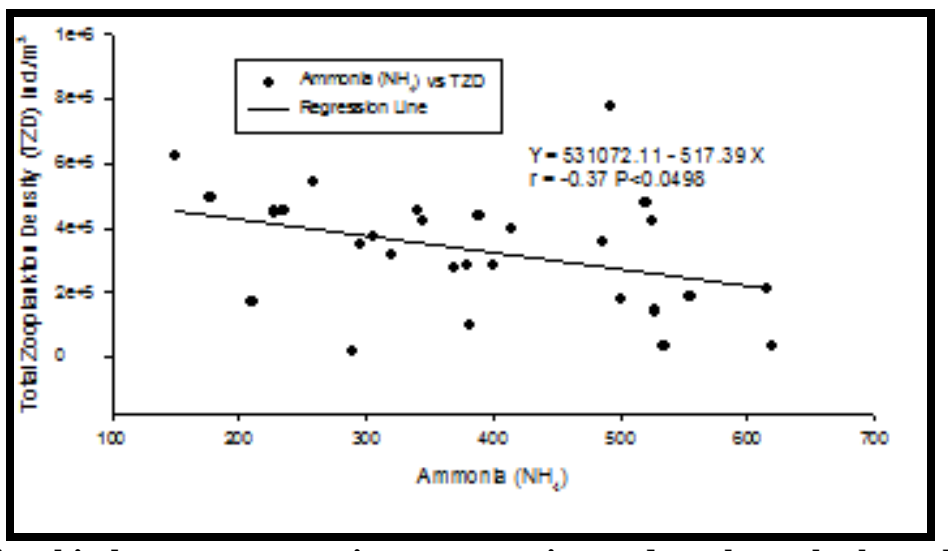

Fig. (8): Relationship between ammonia concentration and total zooplankton density (TZD).

A strong negative correlation was observed between WD and total cladoceran density $(r=-0.697 p<0.0001)$ this is may be because most of cladoceran organisms do not prefer to be near the bottom except Chidorus because (DO) may decrease near the bottom due to oxygen consumption by decayed plant detritus and dead organisms. Furthermore, cladoceran density was found to be negatively influenced by ammonia concentration and water clarity (SD). This is probably due to the increased predation impact on cladoceran species with increasing water clarity.

Water clarity was negatively correlated to total copepod density $(r=-0.48 p<$ 0.01). This is because increased water clarity (SD) may increase the predation impact on the copepods and make them more visible to the predators. 
These results disagree with Fathi et al. (2000) who stated that the maximum transparency was during winter while the minimum was in autumn. On the other side, the present results agreed with those reported by Soliman (1983), Wissa (2002), Fishar et al. (2003), Telesh (2004) and Mageed (2005). The lowest transparency of the drainage waters were in agreement with the results that postulated by Telesh (2004) and Shakweer (2006) and explained that heavy growth of the phytoplankton has an important role in decreasing the transparency of the lake. In addition, Shakweer (2006) found that Barzik Drain has higher TDS concentration than El-Khairy Drain and the later has lower TDS value than the body of the lake; which in turn greatly affect the water clarity. Wissa (2002), Fishar et al. (2003) and Mageed and Heikal (2006) mentioned that, water turbidity is either from the suspended silt and clay or from the heavy growth of the phytoplankton. In addition, the positive correlation between $\mathrm{pH}$ and TR was supported by Moore (1989), Michaud (1991) and Masoud et al. (2004). They clarified that $\mathrm{CaCO}_{3}$ is precipitated at high $\mathrm{pH}$ during photosynthesis in relatively $\mathrm{Ca}$ rich water.

The diatom phytoplankton (Bacilariophycae) is the main consumer of silicate in aquatic ecosystems. Since nutrient compounds and silicate are abundant in the water, they will increase in number. Their increase will be met by high oxygen consumption and accordingly, decrease in total zooplankton density. Therefore, increased silicate was negatively correlated to zooplankton density (Fig. 9). Additionally, decomposition of dead diatoms by microorganisms will consume more oxygen.

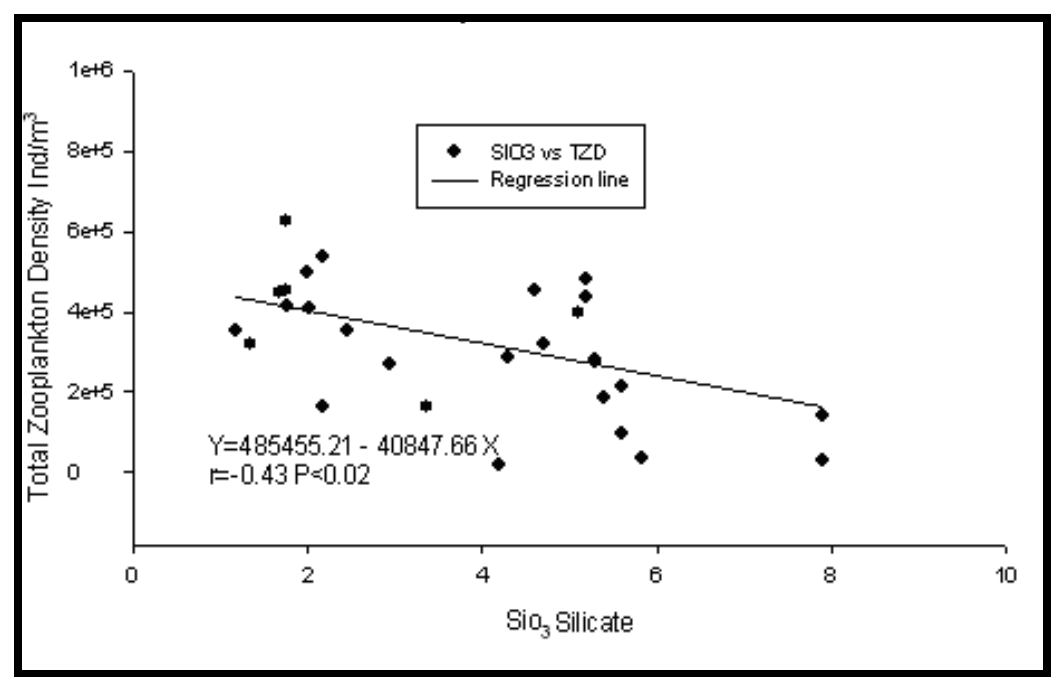

Fig. (9): Relationship between total zooplankton density (TZD) and reactive silicate $\left(\mathrm{SiO}_{3}\right)$.

\section{SPECIES DIVERSITY OF ZOOPLANKTON}

Species diversity, dominance, evenness and species richness can be influenced by several factors such as fluctuations of water characteristics, climate changes, pollution, eutrophication and habitat characteristics.

\section{Analysis of Zooplankton Diversity in Lake Edku}

The lowest number of species (40 species) was recorded in the lake-sea connection, while the highest (53species) was at station 2, in the body of the lake Table (3) whereas, 44 species were recorded in El-Khairy Drain (St. 7). The low number recorded in station 5 , could be due to the influence of water discharged from El-Khairy Drain into the lake near this station.

The species number and species richness for both the drainage and the lake habitats was close to each one which indicates the impact $f$ the drainage discharge on the lake characteristics and more or less the water homogeneity Table (4). The 
community dominance index increased in the lake habitat and lake-sea connection which in turn decreased their diversity.

Table (3): Average of Zooplankton major diversity indices in the studied locations of Lake Edku.

\begin{tabular}{cccccccc}
\hline \hline Stations & Habitat & $\begin{array}{c}\text { Sp. } \\
\text { No. }\end{array}$ & $\begin{array}{c}\text { Sp. } \\
\text { Rich. }\end{array}$ & Shannon* & Margalef & $\begin{array}{c}\text { Community } \\
\text { Dominance } \\
\text { CDI }\end{array}$ & Evenness \\
\hline \hline ST1 & D1 & 52 & 31.75 & 0.909 & 2.475 & 56.94 & 0.605 \\
ST2 & BL2 & 53 & 32.75 & 0.8765 & 2.44 & 60.48 & 0.576 \\
ST3 & BL3 & 49 & 28.25 & 0.822 & 2.09 & 59.705 & 0.57 \\
St4 & BL4 & 47 & 26.25 & 0.772 & 1.94 & 64.05 & 0.546 \\
St5 & BL5 & 39 & 22.00 & 0.7764 & 1.65 & 62.96 & 0.579 \\
ST6 & LSC6 & 40 & 17.5 & 0.704 & 1.49 & 70.807 & 0.571 \\
ST7 & D7 & 44 & 23.5 & 0.933 & 2.01 & 56.017 & 0.687 \\
Average & & 46 & 26.000 & 0.828 & 2.01 & 59.433 & 0.591 \\
SE & & \pm 2.060 & \pm 0.031 & \pm 0.138 & \pm 2.983 & \pm 0.017 \\
\hline \hline Body of the lake & $*$ used the $\log _{10}$ & D $=$ Drainage & LSC $=$ Lake Sea Connection
\end{tabular}

Table (4): Matrix of Diversity Indices for the Studied Habitats

\begin{tabular}{rrrr}
\hline Index & D & BL & LSC \\
\hline Sp. No. & 48 & 47 & 40 \\
Sp. Rich. & 27.63 & 27.31 & 18 \\
Shannon & 0.92 & 0.81 & 0.70 \\
Evenness & 0.65 & 0.57 & 0.571 \\
Margalef & 2.24 & 2.03 & 1.492 \\
CDI & 56.48 & 61.8 & 70.81 \\
\hline
\end{tabular}

Seasonal changes can influence zooplankton diversity, reproduction and distribution. The zooplankton diversity indices increased during winter and summer; however, they decreased during autumn. In addition, the species number was high in winter (Table 5) due to the entrance of some marine species into the lake. This number decreased during spring due to the decreased salinity that led to death of marine species, or increased phytoplankton that led to high oxygen consumption and consequently decreased zooplankton species number.

Table (5) Average of Seasonal Zooplankton Major Diversity Indices In Lake Edku.

\begin{tabular}{lcccccc}
\hline \hline Season & Species No. & Sps. Rich. & Shannon* & Margalef & CDI & Evenness \\
\hline \hline WI & 60 & 26.71 & 0.86 & 2.14 & 56.44 & 0.61 \\
SP & 46 & 24.29 & 0.80 & 1.85 & 66.29 & 0.59 \\
SU & 53 & 27.14 & 0.85 & 2.05 & 58.00 & 0.60 \\
AU & 48 & 25.86 & 0.79 & 2.01 & 65.54 & 0.57 \\
Average & 51.75 & 26.00 & 0.83 & 2.04 & 61.57 & 0.59 \\
SE & 1.502 & 1.207 & 0.029 & 0.095 & 2.35 & 0.019 \\
\hline \multicolumn{7}{r}{$*$ used the $\log _{10}$}
\end{tabular}

The aquatic organisms seem to be affected by increased acidity because most of them may have chitinus, calcareous or siliceous exoskeleton and these protective 
structures might be damaged by decreasing the water $\mathrm{pH}$. In the studied ecosystem, rotifer species only increase by increasing water $\mathrm{pH}$ therefore the evenness and diversity will decrease and dominance index will increase; where they are mostly dominated by one genus, Brachionus. Figure (10) shows the negative correlation between water alkalinity and Shannon and Weaver diversity index.

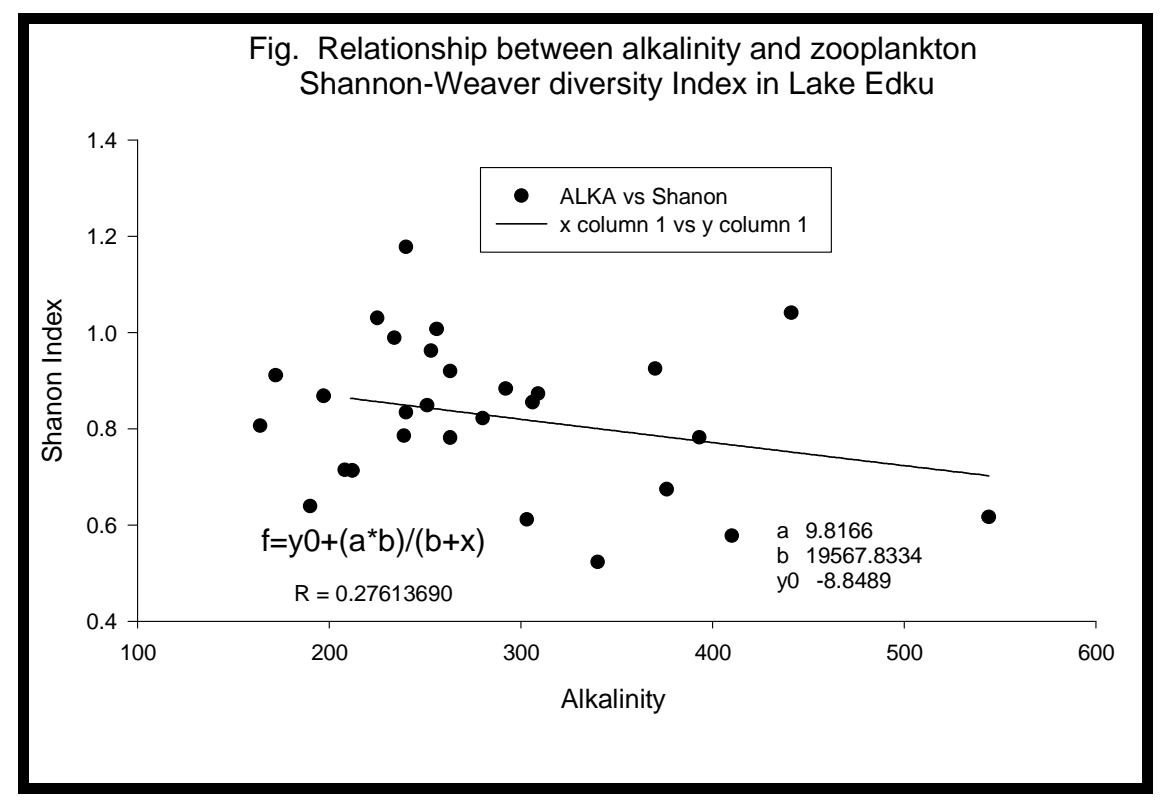

Fig. (10): The relationship between water alkalinity and zooplankton Shannon-Weaver diversity

The diversity index would be higher when two different communities mix together (Margalef, 1958; Gharib, 1999). This may support the increased species number in station 2 due to its location between Taher Drain and the body of the lake. Moreover, the low species richness and species number in station 5 may be attributed to the effect of El-Khairy Drain. These results came in agreement with those reported by Martin et al. (2000) and Abdel-Aziz and Dorgham (2004).

The decrease of the diversity index in the lake-sea connection may be due to the pollutants coming from Abu Qir Bay or due to the continuous fluctuation of salinity and the pollutant coming from Abu Qir Bay which may bring different species. This observation was supported by Odum (1971) and Ostfield and LoGiudice (2003) who stated that loss of biodiversity occurred in communities subjected to seasonal or periodic perturbations by man or nature. Furthermore, youssef (2003) and Abdel-Aziz and Dorgham (2004) explained that estuarine area is characterized by variable and unpredictable environmental conditions, which in turn influence the biodiversity. However, they supported the increase of species number in this habitat during winter and attributed this to the entrance of some marine species. Moreover, Flower (2001) encouraged these results as she postulated that, Delta lakes are rich in phytoplankton diversity but not so for zooplankton diversity. Samaan (1976) illustrated that increased density of submerged hydrophytes was met by a decrease in the number of zooplankton organisms.

In conclusion, comparing the present results with previous data of other researchers showed that zooplankton community in Lake Edku shifted from dominance of Cladocera and large zooplankton species to rotifers and small zooplankton by increasing eutrophication. 


\section{REFERENCES}

Abbas, M. M; Skakweer, L. M. and Youssef, D. H. (2001). Ecological and fisheries management of Edku Lake 1-Hydro-chemical characters of Edku Lake. Bull. Nat. Inst. Oceanogr. Fish. A.R.E., 27: 65-93.

Abdel-Aziz, N. and Dorgham, M. M. (2005). Short-term variations of zooplankton community in the West Nubaria Canal, Alexandria, Egypt. Egypt. J. Aquat. Res., 31: 119-131.

Abdel-Moati, M. A. R. and El-Sammak, A. A. (1997). Man-made impact on the geochemistry of the Nile delta lakes. A study of metal concentrations in sediment. Water Air Soil Pollut., 97: 413-429.

Aboul-Ezz, S. M. and Soliman, M. A. (2000). Zooplankton community in Lake Edku. Bull. Nat. Inst. of Oceanoge. Fish. A. R. E. 26: 71-99.

Ali, M. M.; Mageed, A. A. and Heikal, M. (2007). Importance of aquatic macrophytes for invertebrate diversity in large subtropical reservoir. Limnology. 37: 155169.

APHA (1996). Standard Methods for Examination of Water and Waste Water., 20th. edn. American public Health Association (APHA), New York.

Bedir, T. Z. (2004). Ecological studies on zooplankton and macrobenthos of Lake Burullus. M. Sc. M. SC., Ain Shams University.

Bielan'ska-Grajner, I., Cudak, A.; Biała, A.; Szyman'czak, R. and Sell, J. (2014). Role of spatial and environmental factors in shaping the rotifer metacommunity in anthropogenic water bodies. Limnology 15:173-183 DOI 110.1007/s 10201-10014-10428-10201.

Bishop, J. W. (1968). Respiratory rates of migrating zooplankton in the natural habitat. Limnol. and Oceanogr. 13: 58-62.

Bogdan, K. G. and Gilbert, J. J. (1984). Body size and food size in freshwater zooplankton. Proc. Natl. Acad. Sci. USA. 81: 6427-6431.

Bray, J. R. and Curtis, J. T. (1957). An ordination of the upland forest communities of Southern Wisconsin. Ecological Monographs, 27(4): 326-49.Comita, G. W. (1968). Oxygen consumption in Diaptomus. Limnol. and Oceanogr. 13, 51-57.

Costa, P. F.; Oliveira, R. F. and Fonseca, L. C. D. (2006). Feeding ecology of Neries diversicolor (O.F. Muller) (Annelida, Polychaeta) on estuarine and lagoon environments in the southwest coast of Portogal. Pan-American J. Aquat. Sci. 1: 114-126.

Du, Y.; Gao, S.; Warwick, R. M. and Hua, E. (2014). Ecological functioning of freeliving marine nematodes in coastal wetlands: an overview. 59(34): 4692- 4704 Chin. Sci. Bull. DOI 4610.1007/s11434-11014-10592-z

Dunn, I. G. (1985). Aquatic weed control in relation to fisheries of Lake Edku and Barsik fish farm. FAO corporate document repository. Field Document 1 October 1985.

Einsle, U. (1996). Copepoda Cyclopoida: Genera Cyclops, Megacyclops, Acanthocyclops, p. 1-82. In: H.J.F. DUMONT (Ed.). Guides to the identification of the microinvertebrates of the continental waters of the world. The Netherlands, Backhuys Publishers.

El-Hawary, M. A. (1960). The zooplankton of the Egyptian lakes. Notes and memories, Ministry of Agriculture, Hydrological Department, Alexandria institute of Hydrobiology. 52: 1-20. 
El-Shabrawy, G. M. and Dumont, H. J. (2004). Spatial and seasonal variation of the zooplankton in the coastal zone and main khors of Lake Nasser (Egypt). Hydrob., 491: 119-132.

Fathi, A. A.; Abdelzaher, H. M. A. and Elghany, M. A. (2000). Limnological studies on Edku Lake, Egypt. El-Minia Sci. Bull., 13: 44-60.

Fathi, A. A.; Abdelzaher, H. M. A.; Flower, R. J.; Ramadani, M. and Kraiem, M. M. (2001). Phytoplankton community of North African wetland lakes: the CASSARINA Project. Aquat. Ecol., 35: 303-318.

Fisher, R. A.; Corbet, A. s. and Williams, C. B. (1943). The relation between the number of species and the number of individuals in a random sample of animal population. The Journal of Animal Ecology. 12: 42-58.

Flower, R. J. (2001). Change, stress, sustainability and aquatic ecosystem resilience in North African wetland lakes during the 20th. Century: an introduction to integrated biodiversity studies within the CASSARINA Project. Aquat. Ecol., 35: 261-280.

Froneman, P. W. (2004). Zooplankton community structure and biomass in a southern African temporarily open/closed estuary. Estuar. Coast. Shelf S., 60: 125-132.

Froneman, P. W.; Pakhomov, E. A.; Gurney, L. J. and Hunt, B. P. V. (2002). Predation impact of carnivorous macrozooplankton in the vicinity of Prince Edward Island archiplago (Southern Ocean) in austral autumn 1998. Deep-Sea res. II. 49: 3243-3254.

Gaudy, R.; Borgne, R. I.; Landry, M. R. and Champalbert, G. (2004). Biomass, feeding and metabolism of mesozooplankton in the equatorial Pacific along 180. Deep-Sea research II. 51: 629-645.

Ghabbour, S. I. and Shakir, S. H. (1982). Seasonal variation in a community of soil mesofauna under annual field crops in the Mariut desert. Scientific Reviews on Arid zone Research, 1: 351-377.

Gharib, S. M. (1999). Phytoplankton studies in Lake Edku and adjacent waters (Egypt). Egypt. J. aquat. Biol. Fish., 3: 1-23.

Gharib, S. M. and Dorgham, M. M. (2000). Weekly structure and abundance of phytoplankton in Boughaz El-Maadiya, Egypt. Egypt. J. aquat. Biol. Fish., 4: 183-210.

Hobaek, A.; Manca, M. and Andersen, T. (2002). Factors influencing species richness in lacustrine zooplankton. Acta Oecol., 23: 155-163.

Hrodey, P. J.; Kalb, B. J. and Sutton, T. M. (2008). Macroinvertebrate community response to large-woody debris additions in small warm water streams. Hydrob., 605(1): 193-207

Ismail and Zaidin. (2015). A comparative study of zooplankton diversity and abundance from three different types of water body. $2^{\text {nd }}$ International Conference on Agriculture, Environment and Biological Sciences (ICAEBS'15) Bali (Indonesia). http://dxdoiorg/1017758/IAASTA0715053.

Jacob, K. (2002). Limnology. Upper Saddle River, N.J. Prentice Hall. ISBN-13: 9780130337757

Jeppesen, E., Jensen, J. P., Sondergaard, M., Lauridsen, T. and Landkildhus, F. (2000). Trophic structure, species richness and biodiversity in Danish lakes: changes along a phosphorus gradient. Freshwater Biol., 45: 201-218.

Jeppesen, E.; Meerhoff, M.; Jacobsen, B.; Hansen, R. S.; Sondergaard, M.; Jensen, J. P.; Lauridsen, T. L.; Mazzeo, N. and Branco, C. W. C. (2007). Restoration of shallow lakes by nutrient control and biomanipulation-the successful strategy varies with lake size and climate. Hydrob., 581: 269-285. 
Khan, R. A. (2003). Faunal Diversity of Zooplankton in Freshwater Wetlands of Southeastern West Bengal Zoological Survey. Kolkata of India. p. 107 plates, Records of the Zoological Survey of India: Occasional Paper No. 204.

Khalil, M. T.; Emam, W. M. and Koussa, A. A. (2000). Impaet of wastewater primary treatment on some physico-chemical properties of Lake Maruit, Egypt. J. Egypt. Acad. Soc. Environ. Devel., 1: 1-18.

Koste, W. (1978). Rotatoria die radertiere milleleuropas ein bestimmungswerk. Begrundot Von Max Voigl., 1: 673-234.

Kuczynska-Kippen, N. M. and Nagengast, B. (2006). The inflwence of the spatial structure of hydromacrophytes and differentiating habitat on the structure of rotifera and cladoceran communities. Hydrob., 559: 203-212.

Lair, N. (2005). A biotic vs. biotic factors: lessons from rotifers in the Middle Loire, a meandering river monitored from 1995 to 2002, during low flow periods. Hydrob., 546: 457-472.

Lijing, C.; Qiao, L.; Ziran, P.; Zhongjun, H.; Junzeng, X. and Wu, W. (2012). Rotifer community structure and assessment of water quality in Yangcheng Lake. Chin. J. Oceanol. Limn., 30(1): 47-58, DOI: http://dx.doi.org/2010.1007/s00343-00012-00150-y

Mackintosh, T. J.; Davis, J. A. and Thompson, R. M. (2017). The effect of urbanization on trophic relationship in constructed wetland. Freshw. Sci., 36 (1): $138-150$.

Mageed, A. A. A. (2005). Effect of some environmental factors on the biodiversity of holozooplankton community in Lake Qarun, Egypt. Egypt. J. Aquat. Res., 31: 230-250.

Mageed, A. A. A. and Heikal, M. T. (2006). Factors affecting seasonal patterns in epilimnion zooplankton community in one of the largest man-made lakes in Africa (Lake Naser, Egypt). Limnologica., 36: 91-97.

Margalef, R. (1958). Information theory in ecology. International Journal of General Systems., 3: 36-71.

Martinez-Jeronimo, F. and Martinez-Jeronimo, 1. (2007). Chronic effect of $\mathrm{NaCl}$ salinity on a freshwater strain of Daphnia magna Straus (Crustacea: Cladocera): A demographic study. Ecotox. Environ. Safe., 67: 411-416.

Masoud, M. S.; Elewa, A. A.; Ali, A. E. and Mohamed, E. A. (2004). Metal distribution in water and sediments of Lake Edku, Egypt. Egypt. Sci. Mag., 1: 13-22.

Michaud, J. P. (1991). A citizen's guide to understanding and monitoring lakes and streams. pp. 407-7472. Washington State Dept. of Ecology, Publications Office, Olympia, WA, USA (360).

Mogias, A. and Kevrekidis, T. (2005). Macrozoobenthic community structure in a poikilohaline Mediterranean lagoon (Laki Lagoon, northern Aegean). Helgoland Mar. Res., 59: 167-176.

Moore, M. L. (1989). NALMS management guide for lakes and reservoirs. pp. 5370555443. North American Lake Management Society, P.O. Box 5443, Madison, WI, USA

Mountford, M. D. (1962). An index of similarity and its application to classifica- tory problems. Progress in Soil Zoology, P W Murphy (ed), Butterworth, London. 43-50.

Musa, A. and Héctor, G. (2005). Water resources management in Mexico: The role of the water rights adjustment program (WRAP) in water sustainability and rural development. Mexico. 
Nafea, E. M. A. (2005). On the ecological and sustainability development of the Northern Delta lakes, Egypt. Ph.D., Mansura University.

Odum, E.P. (1997). Ecology a bridge between science and society. Sinauer associates, Inc., Sunderland, Massachusetts, 01375 U.S.A.

Roberts, D. R. and Hsi, B. P. (1979). An index of species abundance for use with mosquito surveillance data. Environ. Entomol., 8: 1007-1013.

Rogozin, A. G. (2000). Specific structural features of zooplankton in lakes differing in trophic status: specific populations. Russ. J. Ecol., 31: 405-410.

Ropert, D. S.; Simons, M. J. and Jones, M. B. (1983). Distribution of zooplankton in the Avon-Heathcote Estuary, Christchurch. New Zealand Journal of Marine and Freshwater Research, 17: 267-278. Ruttner-Kolisko, A. (1974). Plankton rotifer biology and taxonomy. Supplementary edition E. Schwiezerbart'sche Verlagsbuchhandlung (eds., Nageleu Obermiller).

Shiel R, and Koste, W. (1992). Rotifera from Australian inland waters. VIII. Trichocercidae (Rotifera: Monogononta). T. Roy. Soc. South Aust., 116(1): 127.

Saad, M. A. H. (2003). Impact of diffuse pollution on the socio-economic development opportunities in the costal Nile Delta lakes Seventh International Diffuse Pollution Conference. ECSA, Dublin, Ireland.

Sainty, G. (1985). Weed control and utilization of aquatic plants of Lake Edku and Barsik fish farm. FAO corporate document repository. Field document 2 October 1985.

Samaan, A. A. (1974). Primary productivity of Lake Edku. Bull. Nat. Inst. Oceanogr. Fish. A. R. E., 4: 261-317.

Samaan, A. A. (1976). Distribution of zooplankton in Lake Edku. Bull. Nat. Inst. Oceanogr. Fish. A. R. E., 6: 159-196.

Sautour, B. and Castel, J. (1997). Importance of microzooplanktonic crustaceans in the costal food chain: Bay of Marennes-Oleron, France. Oceanol. Acta, 21: 105-112.

Sarkar, C.and Saha, N. C. (2016). A Study on Acute Toxicity of An Insecticide Triazophos on Zooplankton Cyclops Viridis (Jurine, 1820) Along With The Changes in Their Behaviour. Gjra - Global Journal for Research Analysis 5 (11):279-280. ISSN No 2277 - 8160.

Shakir, S. H. and Dindal, D. L. (1997) Density and biomass of earthworms in forest and herbaceous microecosystems in central New York, North America. Soil Biol. Biochem., 29: 275-285.

Shakir Hanna, S. H. (2004). A vision of the role of soil fauna as biological agents for sustainable development in the 21st century. Pages 474-486 in: Shakir Hanna, S.H. and Mikhail, W.Z.A. Soil Zoology For Sustainable Development in the 21st Century. 526 pp + xxxi. Om El-Korra Press, Cairo, Egypt.

Shakweer, L. (2006). Impacts of drainage water discharge on the water chemistry of Lake Edku. Egypt. J.1 aquat. res., 32: 264-282.

Shakweer, L. M. (2005). Ecological and fisheries development of Lake Manzalah (Egypt) 1- Hydrographic and chemical factors in Lake Manzala. Egypt. J. Aquat. Res., 31 (1): 251-270.

Sladecek, V. (1983). Rotifera as indicators of water quality. Hydrobiologia, 100: 169201.

Smironov, N. N. (1996). Cladocera: the Chydorinae Anssayciinae (Chidoridae) of the world. 119pp. SPB Academic Publishing. 
Sokal, R. R. and Rholf, F. J. (1981). Biometry: The principles and practices of statistics in biological research. 2 ed. W. H. Freeman and Company, New York.

Telesh, I. V. (2004). Plankton of the Baltic estuarine ecosystem with emphasis on Neva Estuary: A review of present knowledge and research prespectives. Mar. Pollut. Bull., 49: 206-219.

Thebault, E. and Loreau, M. (2006). The relation between biodiversity and ecosustem functioning in food webs. Ecol. Res., 21: 17-25.

Uku, J. and Mavuti, K. (1999). The feeding differences between larval Oreochromis leucostictus in Oloidien Lagoon compared with the main Lake Nivasha, and Micropterus salmoides. Ecohydrology science and the sustainable management of tropical waters. Eds. UNESCO venice office UNESCO, Paris, 2001., Naivasha, Kenya.

Vaughn, C. C. and Hakenkamp, C. C. (2001). The functional role of burrowing bivalves in freshwater ecosystems. Freshwater Biol., 46: 1431-1446.

Vinebrooke, R. D.; Norberg, K. L.; Stanley, M. S.; Dodson, I.; Maberly, S. C. and Sommer, U. (2004). Impact of multible stressors on biodiversity and ecosystem functioning: The role of species co-tolerance. Oikos., 104: 451-457.

Wallwork, J. A. (1976). The distribution and diversity of soil fauna. Academic Press, San Francisco.

Williamson, C. E. (1983). Invertebrate predation on planktonic rotifers. Hydrob., 104: 385-396.

Williamson, C. E. (1984). Laboratory and field experiments on the feeding ecology of the cyclopoid copepod, Mesocyclops edax. Freshwater Biol., 14: 575-585.

Williamson, C. E. (1987). Predator-prey interactions between omnivourous diaptomid copepods and rotifers: The role of prey morphology and behaviour. Limnol. and Oceanogr., 32: 167-177.

Williamson, C. E. and Bulter, N. M. (1986). Predation on rotifers by the suspentionfeeding calanoide copepod Diaptomus pallidus. Limnol. and Oceanogr., 31: 393-402.

Wissa, J. B. (2002). Ecological studies on benthic invertebrates of Nile River at North Cairo region. Zoology Dept., Ain Shams University.

Wolfnbarger, W. C. (1999). Influence of biotic and a biotic factors on seasonal succession of zooplankton in Hugo Reservoir, Oklahma, U.S.A. Hydrob., 400: 13-31.

Xiong, W.; Li. J.; Chen, Y.; Shan, B.; Wang, W. and Zhan, A. (2016). Determinants of community structure of zooplankton in heavily polluted river ecosystems. Sci. Rep-UK., 6: 22-43.DOI: 10.1038/srep22043 p.

Yildiz, S.; Altindag, A. and Ergönül, M. B. (2007). Seasonal fluctuations in the zooplankton composition of a eutrophic lake: Lake Marmara (Manisa, Turky). Turk J. Zool., 31: 121-126.

Youssef, D. H. (2003). Distribution of Boron in some Egyptian aquatic environments. J. Oceanogr., 59: 537-544.

Zaghloul, F. A. and Hussein, N. R. (2000). Impact of pollution on phytoplankton community structure in Lake Edku, Egtpt. Bull. Nat. Inst. Oceanogr. Fish. A. R. E., 26: 297-318.

Zhao, J.; Ramin, M; Cheng, V. and Arhonditsis, G. B. (2008). Plankton community patterns across a trophic gradient: The role of zooplankton functional group. Ecol. model., 213: 417-36.

Zingel, P. and Haberman, J. (2008) A comparisonof zooplankton densities and biomass in Lakes. Hydrob., 599: 153-159. 


\section{ARABIC SUMMARY}

\section{تركيب مجتمع هائمات المياه العذبة الحيوانية في بحيرة ادكو- جمهورية مصر العربية}

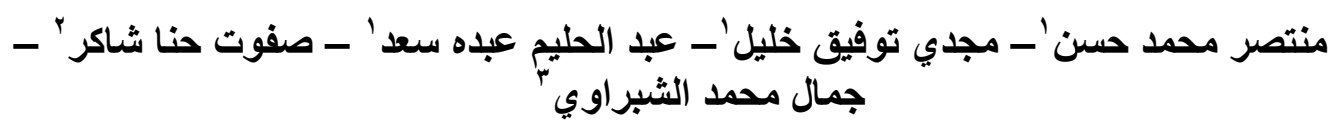

$$
\begin{aligned}
& \text { 1 - قسم علم الحيوان - كلية العلوم - جامعة عين شمس، مصر }
\end{aligned}
$$

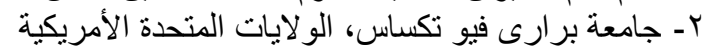

$$
\begin{aligned}
& \text { r- المعهد القومي لعلوم البحار و المصايد بالقناطر الخيرية، مصر الإيكر }
\end{aligned}
$$

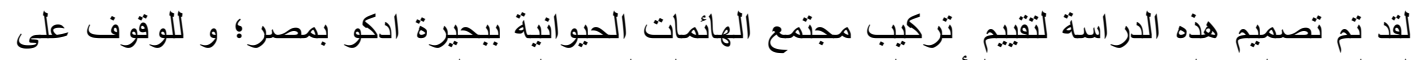

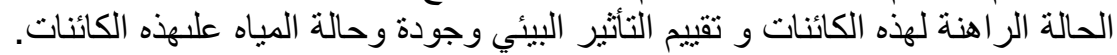

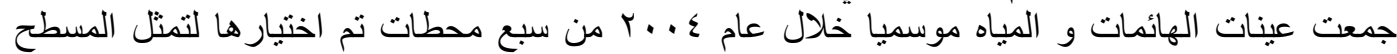

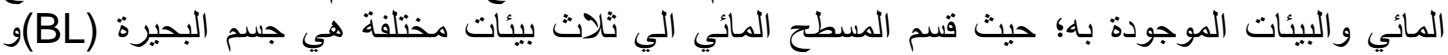

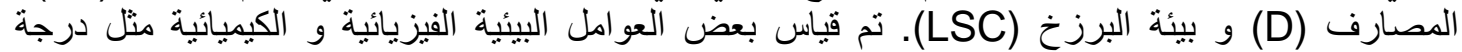

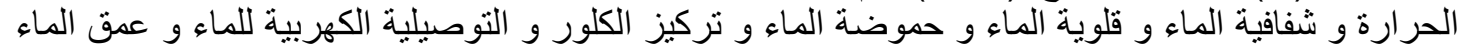

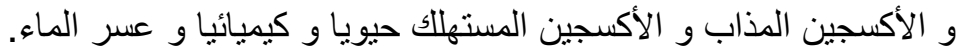

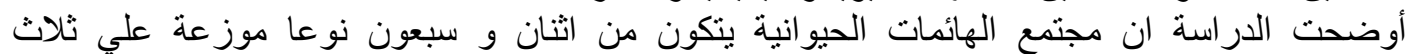

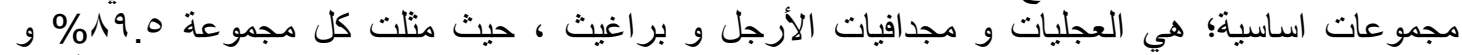

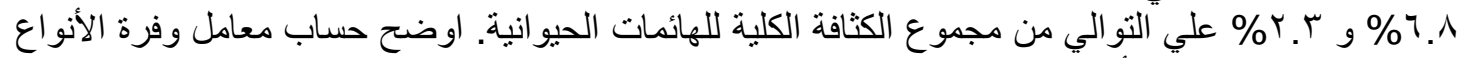

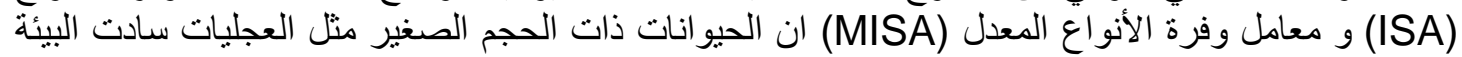

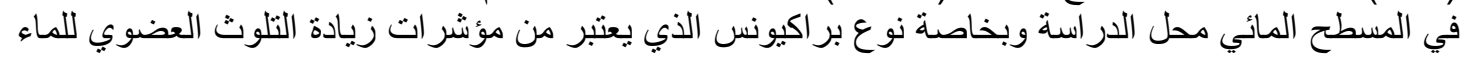

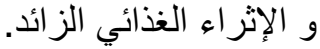

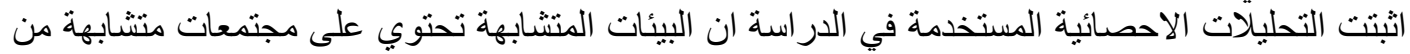

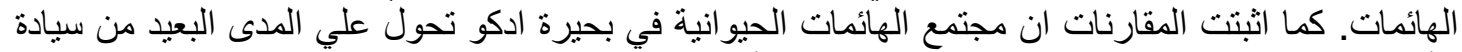

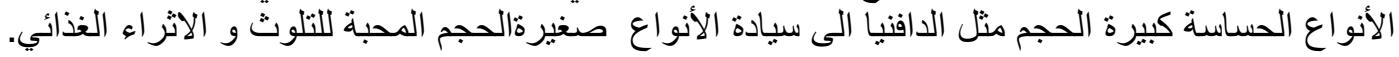

